\title{
Biological Effects in Lung Cells In Vitro of Exhaust Aerosols from a Gasoline Passenger Car With and Without Particle Filter
}

\author{
Christoph Bisig $^{1} \cdot$ Sandro Steiner $^{1} \cdot$ Pierre Comte $^{2} \cdot$ Jan Czerwinski $^{2}$.

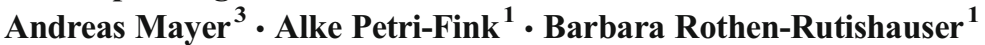

Received: 14 February 2015 /Revised: 8 June 2015 / Accepted: 9 June 2015 / Published online: 9 July 2015

(C) The Author(s) 2015. This article is published with open access at Springerlink.com

\begin{abstract}
Exhaust aerosol from gasoline passenger cars is a complex mixture of a particulate fraction as well as volatile compounds. In contrary to the observed adverse effects of diesel exhaust particles the gasoline exhaust has, however, received little attention so far. The aim of this study was to perform a comparison of exhaust composition and biological responses from freshly produced non-filtered exhaust as well as from exhaust filtered with a noncoated gasoline particle filter (GPF). A 3D model of the human epithelial airway barrier was exposed to the exhaust directly at the air-liquid interface and different effects such as cytotoxicity, antioxidative response, pro-inflammation, and activation of the aryl hydrocarbon receptor (AhR) were studied. In addition, genotoxicity was assessed using the Ames test. By an online analysis of the exhaust, it has been shown that the GPF efficiently filters the particle count in both the cold and warm phase when the new European driving cycle (NEDC) was applied. The lung cell tests revealed that the use of the GPF increased the antioxidative glutathionine (GSH) response as well as the proinflammatory potential, i.e., $I L-8$, expression, indicating
\end{abstract}

Christoph Bisig and Sandro Steiner contributed equally to this work.

Electronic supplementary material The online version of this article (doi:10.1007/s40825-015-0019-6) contains supplementary material, which is available to authorized users.

Barbara Rothen-Rutishauser

barbara.rothen@unifr.ch

1 Adolphe Merkle Institute, University of Fribourg, Chemin des Verdiers 4, 1700 Fribourg, Switzerland

2 Bern University for Applied Sciences, 2560 Nidau, Switzerland

3 TTM, Technik Thermischer Maschinen, 5443 Niederrohrdorf, Switzerland increased cell stimulation by the volatile compounds alone. The removal of the particulate fraction, however, decreased significantly the AhR activation in comparison to unfiltered exhaust, and the exhaust genotoxicity was reduced as tested by the Ames test. In conclusion, GPF exhaust did not completely reduce the adverse effects of gasoline exhaust in the in vitro test and further experiments with a coated GPF are needed in the future.

Keywords gasoline $\cdot$ exhaust emissions $\cdot$ in vitro 3D lung model $\cdot$ air-liquid interface $\cdot$ gasoline particle filter $\cdot$ toxicity

\section{Introduction}

Studies for gasoline-fueled internal combustion engines point out that this vehicle class can emit remarkable amounts of particles, up to $10^{8}$ particles $/ \mathrm{cm}^{3}$ in certain cases [1-3] Especially gasoline direct injection (GDI) technology shows particle number (PN) emissions significantly higher than modern diesel cars equipped with best available diesel particle filter technology. Since the trend for gasoline vehicles with GDI technology is increasing, a significant rise in emission is predicted in the near future.

The emissions of combustion-derived nanoparticles (NPs), i.e., particles with a diameter of less than $100 \mathrm{~nm}$, are produced especially at cold starts and warm-up conditions as well as at a dynamic engine operation [4]. The lube oil contributes to this emission and affects number concentrations of nuclei mode particles and chemical exhaust composition $[5,6]$.

The investigations of the NP morphology from GDI engine revealed principally graphitic structures, which can store some metal oxides in certain conditions and can be coated by condensates [7, 8]. NP count concentrations are limited in EU for diesel passenger cars since 2013 and for GDI cars since 2014; 
this limit for GDI cars was temporarily extended to $6 \times 10^{12}$ particles $/ \mathrm{km}$ (regulation no. 459/2012/EU), and with a gasoline particle filter (GPF), it has been shown that the NPs can be eliminated [9].

The lung is the main portal of entry for inhaled exhaust emissions such as diesel particles which have been associated with lung cancer [10]. Reduction in emission of exhaust constituents are readily measured by technical means to ensure better environmental protection; however, estimating how current and new combustion engine technologies actually affect exhaust toxicity in humans is difficult. Standardized protocols for exhaust toxicity assessment are lacking and it relies in many aspects on epidemiological and in vivo studies (animals) [11, 12], which are time and cost-intensive and suffer from considerable ethical issues. There is an urgent need to establish realistic and well accepted in vitro alternatives; we focused on such a risk assessment with an in vitro human lung cell model alternative [13]. To study the cellular interplay and cellular responses following exhaust emission exposures at the cellular level in human lung cells, a triple-cell co-culture model system composed of epithelial lung cells (16HBE14ohuman bronchial cells), monocyte-derived macrophages (MDM), and monocyte-derived dendritic cells (MDDC) has been established [14]. This model mimics the epithelial airway barrier and has been evaluated in terms of their functional relevance in vivo [13-15].

The triple-cell co-culture model is routinely used to study the toxic potential of various NPs when applied in suspension such as diesel exhaust particles or engineered NPs, e.g., titanium dioxide [16], as well as for high aspect ratio nanomaterials such as carbon nanotubes [17] or cellulose nanocrystals [18]. In addition, the cultures function at the airliquid interface (ALI) allowing the direct exposure of the cell culture surface to a defined aerosol or a complete engine emission sample, thus representing the realistic situation following inhalation [19-21]. Different endpoints including numerous biochemical and molecular markers can be assessed to investigate the potential toxicological response in lung cells after exhaust exposures (for a review, see [22]), such as cytotoxicity, oxidative stress, and pro-inflammatory effects [18, 23-25].

Exposure of submerged cells to sampled exhaust components suspended in cell culture medium does not represent a realistic scenario; therefore, many sophisticated systems have been developed recently to bring a freshly produced exhaust directly onto the lung cells [21, 25-29]. Exhaust samples can be taken directly at the tailpipe and brought to the lung cell cultures with a delay of less than $30 \mathrm{~s}$ [29]. Such a system has the advantage that the exhaust components, i.e., the particulate fraction as well as the volatile compounds, can be analyzed online and do not suffer from biased sample generation [30, 31].

The combined use of the exhaust exposure at the ALI and a model of the human airway epithelial barrier $[32,33]$ is the base for the efficient and reliable investigation of exhaust toxicity in a standardized manner without the need for invasive animal or ethically entangled human exposures.

In the current study, we have investigated the effects of emissions produced from a gasoline vehicle in combination with a GPF. The exhaust from a car driven by the new European driving cycle (NEDC) repeated for $6 \mathrm{~h}$ was directly exposed onto the lung cell surface of a $3 \mathrm{D}$ in vitro model of the human epithelial airway barrier. In parallel the exhaust was characterized online in order to correlate any cell response with the exhaust constituents. After $6 \mathrm{~h}$ gasoline exhaust exposure, the cells were placed into the incubator for $6 \mathrm{~h}$ postexposure, and then, the cells and supernatants were fixed and collected to perform various assays to determine a possible cell response, e.g., cytotoxicity, oxidative stress, pro-inflammation, and aryl hydrocarbon receptor (AhR) activation. In addition, the Ames test was performed to assess the genotoxic potential of the exhausts.

\section{Materials and Methods}

\subsection{Cell Cultures}

A triple-cell co-culture model of the human epithelial airway barrier was used as previously described [34]. Briefly, 16HBE140- cells (human bronchial epithelium airway cell line [35]) were seeded on insert membranes and cultured for 5 days before adding human MDM on top and human MDDC on the bottom of the insert. Human whole blood monocytes were isolated from buffy coats provided by the blood donation service SRK Bern and purified using CD14 Microbeads (Milteny Biotech) as described by Steiner et al. [36].

Prior to exposure, the cell cultures were transferred to the ALI for $24 \mathrm{~h}$. The cells were exposed to filtered air (reference chamber) or diluted exhaust continuously for $6 \mathrm{~h}$, followed by $6 \mathrm{~h}$ post-incubation in the incubator. After post-incubation, cells and cell culture media were collected and immediately fixed or stored. Positive controls confirmed the functionality of the performed assays and the responsiveness of the cells to a certain stimuli. Negative cell culture controls which were kept in the incubator (not shown) confirmed the quality of the cell cultures. Analyses of the samples were performed as described below.

\subsection{Ames Test Bacteria}

The mutagenicity on bacteria was tested using the Ames MPF 98/100 microplate format assay (S. typhimurium strains TA98 and TA100, Xenometrix).

Bacterial cultures were exposed to diluted exhaust for 2 , 4 , and $6 \mathrm{~h}$ directly in the exposure chamber. Using different 
time points allow for analysis of different "doses," as the longer the bacteria is exposed, the more exhaust is deposited. As with the cell cultures, control cultures were exposed to filtered air in the reference chamber. Positive bacterial controls were treated with $2 \mu \mathrm{g} / \mathrm{ml}$ 2-nitrofluorene (TA98) and $0.1 \mu \mathrm{g} / \mathrm{ml}$ 4-nitroquinoline $\mathrm{N}$-oxide (TA100), according to the kit manufacturer's protocol. After exposure, the bacterial cultures were kept in histidine-free culture medium for $48 \mathrm{~h}$ prior to counting the number of revertant colonies. Since all mutagens are genotoxic, we used the latter term throughout the text.

\subsection{Test Vehicle and Exposure System}

A gasoline passenger car from the year 2013 (Euro 5b+exhaust class) was driven on a chassis dynamometer with standard market gasoline (RON 95) and dexos2-SAE5W-30 (the original lubricant). The vehicle was still equipped with its original three-way catalytic converter, and neither the catalytic converter itself nor the electronic control was modified. The NEDC was repeated for $6 \mathrm{~h}$. The exhaust exposure experiments were conducted as already described [34]. Briefly, 10fold diluted exhaust was cooled to $37^{\circ} \mathrm{C}$ and sucked through the chamber with the cells with a constant volume flow of $2 \mathrm{~L} \mathrm{~min}{ }^{-1}$. Except for the presence or absence of exhaust, the conditions in the exposure and reference chamber were kept identical and stable at $37{ }^{\circ} \mathrm{C}, 85 \%$ relative humidity and $5 \% \mathrm{CO}_{2}$.

The GPF used was a new, noncoated wall flow particle filter with cordierite, a porosity of $50 \%$, a pore size of $19 \mu \mathrm{m}$, and 200 cells per square inch.

\subsection{Exhaust Characterization}

The exposure experiments and hence the online exhaust characterization were performed at the exhaust gas control station of the Bern University of Applied Sciences in Nidau, Switzerland, an institution officially accredited for exhaust gas control by the Swiss government. Exhaust sample characterization (in terms of particulate and gaseous components) is performed in parallel to the exposure experiments, yielding detailed and unbiased information on a part of the very same emission sample the cells were exposed to. All measurements have been performed by qualified personnel according to the requested protocols.

The PN was measured in the 10 -fold diluted exhaust using a condensation particle counter: TSI 3790 . Furthermore, the concentrations of carbon monoxide (CO), carbon dioxide $\left(\mathrm{CO}_{2}\right)$, total gaseous hydrocarbons $(\mathrm{HC})$, and nitrogen oxides (NOx) were measured using a Horiba MEXA-9400H exhaust gas measuring system.

\subsection{Cell Sample Analyses}

After exposure to the exhaust the cell sample analyses, i.e., fixed cells, collected cell lysates, and supernatants, were performed according to established and standardized protocols as previously described [34, 36-38]. The combined cell responses were assessed using collected cells/supernatants from the $3 \mathrm{D}$ cell model and therefore the effects could not be assigned to a specific cell type but rather reflects the response in an airway tissue. Shortly, the different assays were performed as follows:

Quantification of Extracellular Lactate Dehydrogenase The viability of the cells was tested using the LDH detection kit (Cytotoxicity Detection Kit (LDH), Roche Applied Science) according to the manufacturer's protocol. The release of LDH for a positive control was done with $0.25 \%$ Triton $\mathrm{X}-100$.

Laser Scanning Microscopy (LSM) LSM was used to evaluate the morphology of the cells after the exhaust exposures. Samples were fixed in $3 \%$ paraformaldehyde, permeabilized with $0.25 \%$ Triton X-100, labeled with mouse anti $\alpha$-tubulin antibodies (secondary labeling with Cy3 conjugated goat anti-mouse antibodies, labeling the tubulin cytoskeleton), phalloidin Alexa 633 (labeling FActin cytoskeleton), and 4',6-diamidino-2-phenylindole (DAPI, labeling nucleic acids). Image acquisition was performed on a Zeiss LSM 710.

Quantification of Total GSH The glutathione assay kit (indication of oxidative stress, Cayman Chemical, provided by Adipogen AG, Liestal, Switzerland) was performed according to the manufacturer's protocol using cell lysates. In order to account for possible variations in the cell number in different cell cultures, GSH concentrations were normalized to the total protein content of the cultures (BCA protein assay kit, Pierce). For the positive control for oxidative stress, tert-butyl hydroperoxide ( $500 \mu \mathrm{L}, 5 \mathrm{mM}$ in PBS) was put on top of the membrane and left there for $6 \mathrm{~h}$.

Gene Expression Analysis Real-time reverse transcriptase polymerase chain reaction (real-time RT-PCR) was performed as previously described. RNA was isolated using the RNeasy plus kit (Qiagen). Per reverse transcriptase reaction, isolated RNA $(6.5 \mu \mathrm{L}, 250 \mathrm{ng})$, oligo-dT primer $(1 \mu \mathrm{L}, 10 \mu \mathrm{M}$, Qiagen), RNase inhibitor $(0.25 \mu \mathrm{L}$, RNasin Plus RNase Inhibitor, Promega), dNTP Mix (1 $\mu \mathrm{L}, 5 \mathrm{mM}$, Qiagen), Omniscript reverse transcriptase $(0.25 \mu \mathrm{L}, 1 \mathrm{U}$, Qiagen $)$, and buffer RT ( $1 \mu \mathrm{L}$, Qiagen) were used to synthesize complementary DNA (cDNA). The master mix for the real-time PCR consisted of nuclease-free water $(2 \mu \mathrm{L})$, SYBR-green mix $(5 \mu \mathrm{L}$, Fast SYBR Green master mix, Applied 
Biosystems), and primer mix $(2 \mu \mathrm{L}, 91 \mathrm{nM})$. The mix was added to $2 \mu \mathrm{L} 10$-fold diluted cDNA, and PCR was performed on the 7500 fast real-time PCR system, Applied Biosystems.

Relative expression levels were calculated using the ${ }^{\Delta \Delta} \mathrm{Ct}$ method with glyceraldehyde-3-phosphate dehydrogenase $(G A P D H)$ as an internal standard gene. Heme oxygenase 1 (HMOX1), superoxide dismutase 2 (SOD2), and glutathione reductase $(G S R)$ were genes used to measure oxidative stress. For pro-inflammatory responses, tumor necrosis factor $\alpha$ $(T N F \alpha)$ and interleukin-8 (Il-8) were assessed. AhR activation was assessed by the genes coding for following proteins: indoleamine 2,3-dioxygenase 1 (IDO-1), transcription factor NFE2-related factor 2 (NFE2L2), cytochrome P450 1A1 (CYP1A1), UDP-glucuronosyltransferase 1-6 (UGT1A6), and $\mathrm{NAD}(\mathrm{P}) \mathrm{H}$ dehydrogenase [quinone] 1 (NQO1). The primer sequences for all assessed genes can be found in the supporting information Table S1.

\subsection{Data Processing and Presentation}

Data Normalization For the assessed biological endpoints, the value obtained on 1 day of exhaust exposure was normalized to the value obtained after reference exposure on the same day. This normalization was performed for two reasons: (i) independently on the presence of exhaust in the exposure chamber, certain biological responses to the treatment may have been induced (for example by the continuous stream of air in the exposure chamber). This made elimination of nonexhaust related effects (which can be assumed to be the same after exhaust and air exposure) by normalization to the reference necessary. (ii) The variability between two sets of cell cultures (mainly due to the presence of immune cells obtained from different blood donors) inevitably results in different baseline values for any assessed biological response. Even if the baseline level of a given biological parameter is not the same in different sets of cell cultures, the fold change in this parameter in response to a certain stimulus is comparable. Normalization to an assumed zero-effect level, in this case the level measured in the reference cultures, is therefore a valid method for data smoothening.

For the Ames test, according to the kit manufacturer's recommendation, all values smaller than 1 were set to 1 in addition to normalization to the reference.

\section{Statistical Analysis and Definition of Significant Results} The number of repetitions was $n=4$ for GPF and $n=3$ for no GPF exhaust, unless otherwise stated in the figure caption; all assays were performed in triplicate. An independent two-sided Student's $t$ test using Excel was performed, comparing filtered and unfiltered exhaust only [39]. All results are presented as average \pm standard error of the mean (SEM), and $p$ values below $5 \%$ were considered statistically significant.
For the Ames test, according to the manufacturer's recommendation, a 3-fold or higher increase in the number of revertants in exposed cultures compared to the reference or the presence of a clearly discernible dose response was considered as indicative for genotoxic effects.

\section{Results}

\subsection{Exhaust Composition}

The investigated parameters for the gaseous fraction were carbon monoxide (CO), total hydrocarbon (THC), nonmethane hydrocarbon (NMHC), mono-nitrogens $\mathrm{NO}$ and $\mathrm{NO}_{2}\left(\mathrm{NO}_{\mathrm{x}}\right)$, and carbon dioxide $\left(\mathrm{CO}_{2}\right)$. This gaseous fraction of the exhaust was not altered with the addition of the GPF (supporting information Figs. S1 and S2). High concentrations of CO were measured, and regardless of the setup, this $\mathrm{CO}$ enrichment occurred especially in the cold phase and in high velocities $(100-120 \mathrm{~km} / \mathrm{h})$.

The GPF reached a particle count filtration efficiency of $99.8 \%$ in the cold cycle and $99.99 \%$ in the warm cycles. In the 10 -fold diluted exhaust, an average particle count of $2.6 \times$ $10^{5}$ particles $/ \mathrm{cm}^{3}$ without GPF $(n=3)$ and 28.7 particles $/ \mathrm{cm}^{3}$ with GPF $(n=4)$ were measured (supporting information Figs. S3, S4, and S5).

The GPF created some additional backpressure for the engine but still in the accepting range of the on-board diagnostics. It seems therefore that the function of the catalytic converter was not influenced nor did we notice any system response which would have indicated such an influence.

\subsection{Cell Viability}

No changes in cellular morphology or ruptures in the epithelial layer could be detected by LSM (Fig. 1a) for any of the exposure conditions, i.e., with or without GPF. The quantification of the extracellular LDH activity revealed no membrane disruption (Fig. 1b).

\subsection{Oxidative Stress and Antioxidative Response}

GPF-filtered exhaust resulted in a significant decrease in the GSH levels, an antioxidative stress-responsive protein, by about $50 \%$ in comparison to the air control, while unfiltered exhaust only moderately decreased the GSH levels by about $15 \%$ (Fig. 2a).

Interestingly, according to the genes SOD2 and GSR (Fig. 2b), filtered exhaust overall appears to have resulted in a lower response to oxidative stress than unfiltered exhaust: SOD2 expression was increased $1.5 \pm 0.5$-fold by unfiltered exhaust but suppressed to $0.7 \pm 0.1$-fold activity by filtered exhaust. The according values for GSR are $4.1 \pm 2.8$ (no 
Fig. 1 Cell viability and morphology after exhaust exposures. a Laser scanning microscopy images visualizing the F-actin cytoskeleton (purple), a-tubulin (orange), or the cell nuclei (light blue) indicate no effects on the cell morphology at either condition. b Quantification of extracellular LDH shows no cell death. Error bars indicate SEMs. Experimental repetitions are for no GPF $(n=3)$ and GPF $(n=4)$. The respective controls are shown as white bars (color figure online)

\section{A \\ Reference \\ (filtered air)}

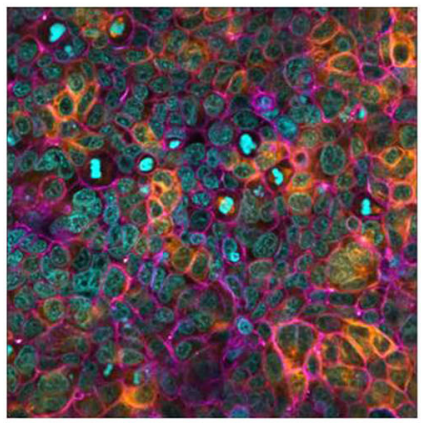

Gasoline exhaust

(GPF)

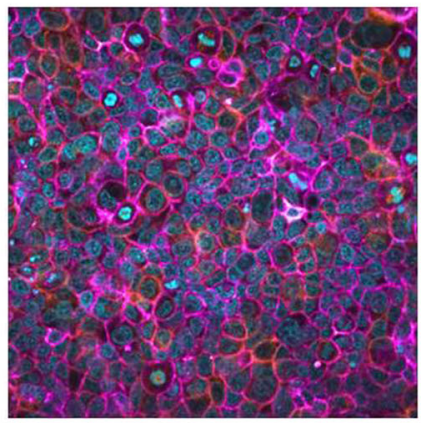

Gasoline exhaust (no GPF)

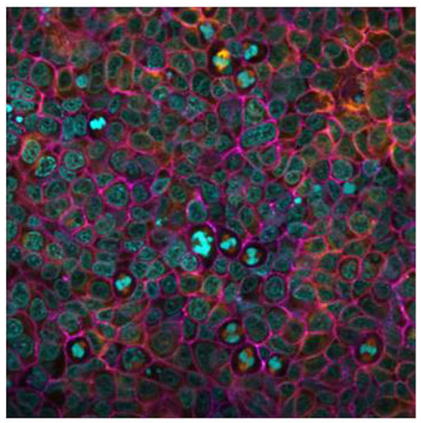

B

\section{Cytotoxicity (LDH)}

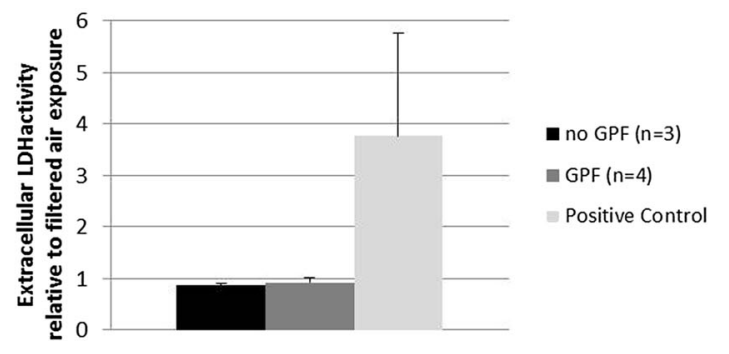

GPF) and 1.3 \pm 0.2 (GPF). HMOX1 expression was induced $3.1 \pm 1.3$-fold by unfiltered exhaust and $4.3 \pm 3.2$-fold by filtered exhaust.

\subsection{Pro-Inflammation}

The gene expression levels of both assessed genes, $T N F \alpha$ and $I l-8$, were found to be increased by filtered exhaust $(1.7 \pm 0.6$ fold and 6.6 \pm 5.8 -fold, respectively), whereas unfiltered exhaust decreased the expression of both genes (to $0.5 \pm 0.2$-fold and $0.7 \pm 0.1$ ) (Fig. 3).

\subsection{AhR Activation}

Whereas no effects of filtered exhaust could be detected for any of the assessed genes (changes in gene expression levels smaller than 2-fold), clear effects were observed for unfiltered exhaust (Fig. 4). NFE2L2 expression was increased 3.1 \pm 2.2 fold, indicating the activation of NFE2-related factor 2dependent signaling. Also, genes whose products are involved in the detoxification of xenobiotics were activated (UGT1A6 2.6 \pm 1.6-fold, NQO1 5.5 \pm 3.2 -fold). NFE2L2 and NQO1 gene expression was significantly higher in unfiltered exhaust compared to filtered exhaust.
A

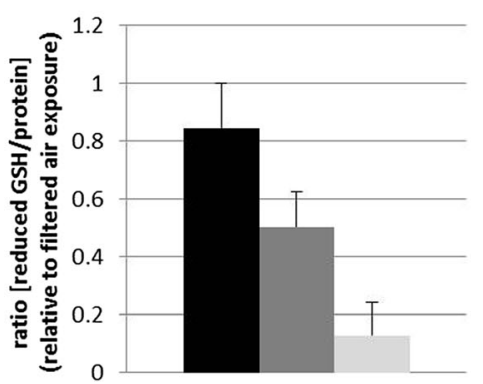

B Oxidative stress-related gene expression (HMOX1, SOD2, GSR)

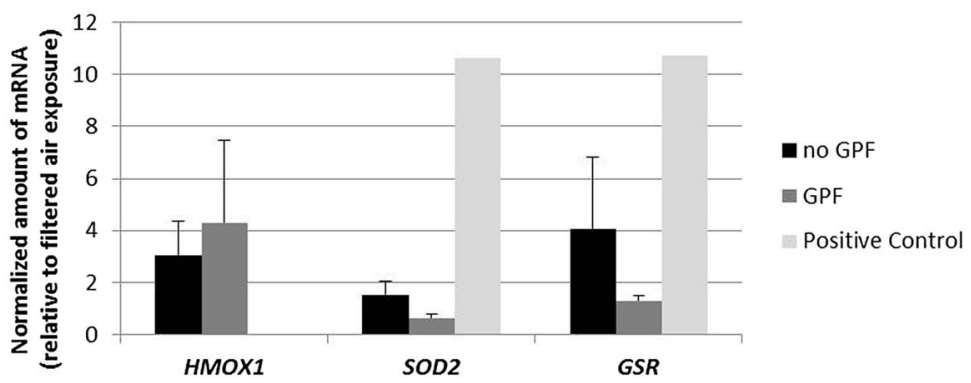

Fig. 2 Oxidative stress in cells exposed to the various exhausts. a Antioxidative stress. Exhaust-related oxidation of the antioxidative molecule GSH reveals more stress in cells exposed to the filtered exhaust which is however not significant. b Oxidative stress. Transcriptional response to oxidative stress of three oxidative stress- responsive genes indicating an increased oxidative stress upon exposure to unfiltered exhaust for SOD2 and GSR. Error bars indicate SEMs. Experimental repetitions are for no GPF $(n=3)$ and GPF $(n=4)$. The respective controls are shown as white bars 


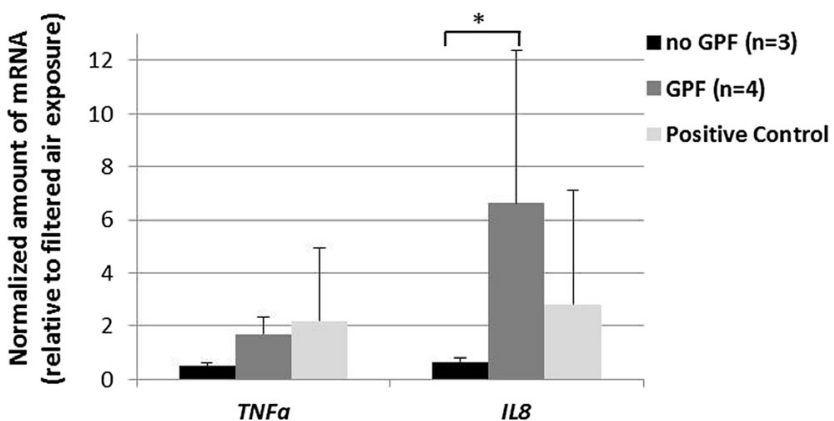

Fig. 3 Exhaust-related changes in the transcriptional activity of two proinflammatory genes, i.e., $T N F a$ and $I L-8$. Filtered exhaust increases the $I L-8$ gene expression. Error bars indicate SEMs. Experimental repetitions are for no GPF $(n=3)$ and GPF $(n=4) .{ }^{*} p>0.05$ no GPF vs GPF. The respective controls are shown as white bars

\subsection{Genotoxicity}

A genotoxic dose response dependent on the exposure time was observed in S. typhimurium strain TA100 for unfiltered exhaust (Fig. 5a). However, at no time points (2, 4, or $6 \mathrm{~h}$ ), a fold change in revertants of more than 3 was observed (fold induction of $1.5 \pm 0.4,1.8 \pm 0.8$, and $2.8 \pm 0.9$, respectively). Also, a weak dose response could be seen in strain TA98 (Fig. 5b), but prolonged exposures would be needed to confirm this. Filtered exhaust did not act genotoxic in neither of the two strains.

\section{Discussion}

The effects of exhaust emitted from a gasoline passenger car with and without particle filter were assessed by using a welldefined and characterized exhaust exposure system which has been used for scooter as well as diesel exhausts in combination with different after-treatment technologies or fuels [21, 25, 29, 34, 36-38, 40]. As expected, the GPF reduced the PN significantly and the concentrations of the volatile compounds

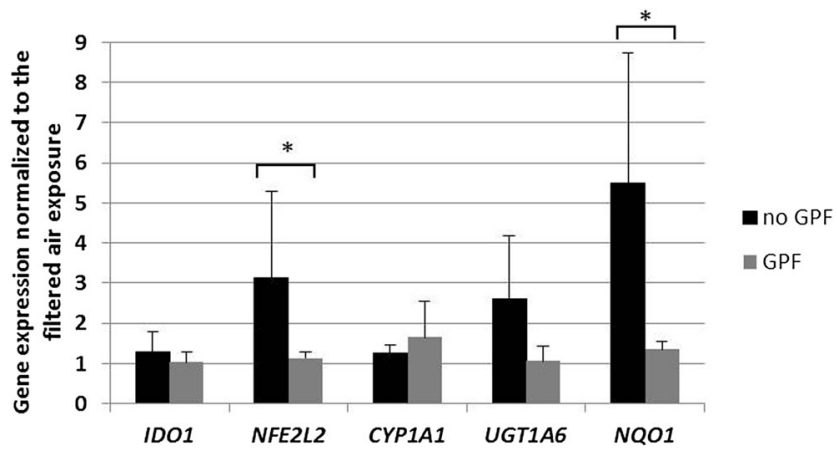

Fig. 4 Exhaust-related changes in the transcriptional activity of five AhR-responsive genes. Unfiltered exhaust increases three out of five tested genes while unfiltered does not alter the mRNA levels compared to control cultures. Error bars indicate SEMs. Experimental repetitions are for no GPF $(n=3)$ and GPF $(n=4) .{ }^{*} p>0.05$ no GPF vs GPF. The respective controls are shown as white bars did not change. A 10-fold dilution of the exhaust was chosen based on our previous work using diesel emissions [34] representing a highly polluted site [41]. Also, a 10-fold dilution resulted in PN concentrations similar to on-road studies in Los Angeles [42] and Israel [43] where ambient measurements have been performed. In a study from Reed and colleagues [44], different dilutions of gasoline engine exhaust were tested ranging from 1:10 to 1:90, and significant effects in rodents were only observed for the higher dose, i.e., 1:10 1:15 dilutions.

The cellular effects induced by the two exhaust types are summarized in Table 1, indicating that the removal of the particulate exhaust fraction alone is not sufficient to eliminate all adverse effects in vitro. This is in line with in vivo studies, which report toxic effects of gasoline exhaust, particularly also after filtration with a GPF $[44,45]$. Epidemiological studies on the other hand could not find or find only weak associations between gasoline engine exhaust and e.g. lung cancer [46-48].

No cytotoxicity or changes in cell morphology were observed for both exhaust classes, but an induction of antioxidative stress response (GSH assay) in comparison to the cells exposed only to clean air was measured. This induction was considerably stronger for the filtered exhaust, and even though between filtered and unfiltered exhaust, no statistically significant difference can be observed. Interestingly, the induction of oxidative stress responsive genes was comparable or weaker for filtered exhaust. A decrease in antioxidative response was also observed in the same exhaust exposure setup when a diesel engine in combination with an uncatalyzed diesel particle filter (DPF) was used, but there a similar response for the nonfiltered diesel exhaust was found [34]. More oxidative and antioxidative genes/proteins should be studied in further experiments.

Additional to the observed reduced antioxidative response, an increase of pro-inflammatory effects was measured for the filtered gasoline exhaust, while no effects on the pro-inflammatory potential were observed for the unfiltered exhaust. It is important to note that changes of gene expression levels of less than two are usually not considered biologically relevant, therefore only the induction of $I L-8$ upon exposure to filtered exhaust should be considered as a real effect.

Since the AhR controls the transcriptional activity of a wide variety of genes whose gene products are involved in immunomodulation, antioxidant responses, and the detoxification of xenobiotics [49], the mRNA expression analysis of AhR-related genes was investigated. The results indicate that the use of a GPF is able to remove toxic exhaust components, at least with respect to the subset of xenobiotics that activate AhR signaling. In contrary, the unfiltered exhaust clearly showed the induction of some of the investigated AhRresponsive genes. These findings are in-line considering the 


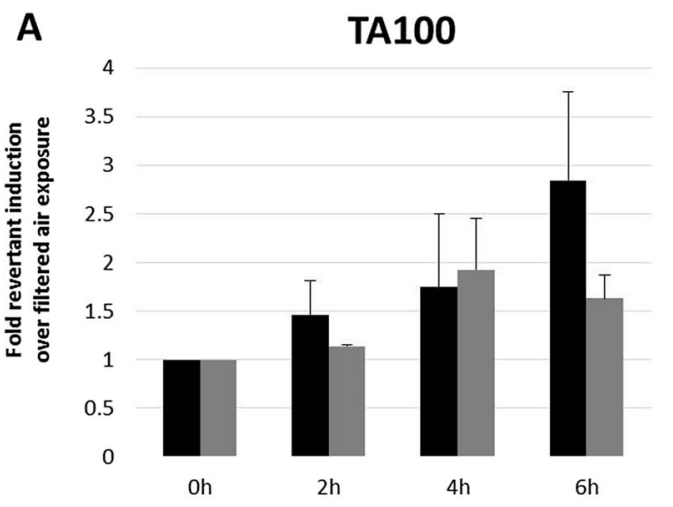

Fig. 5 Genotoxicity on bacteria. AMES tests were performed with a Salmonella typhimurium, strain TA100 and b Salmonella typhimurium, strain TA98. A fold change relative to the control in the number of revertant colonies of 2 or higher and the presence of a clear dose

main ligands for AhRs are polycyclic aromatic hydrocarbons (PAHs) [50]. Nonfiltered exhaust also induced genotoxicity in the Ames test (in S. typhimurium strain TA100) after $6 \mathrm{~h}$ of exposure; a weak dose response for a longer exposure can be observed. In strain TA98, only a small increase in revertants for nonfiltered exhaust is visible. A weaker dose response is also visible in strain TA98, but prolonged exposures would be needed for a more clear answer.

Using a similar experimental setup as in the present study, Steiner et al. [34] could show that the filtration of diesel exhaust by an uncatalyzed DPF decreases the pro-inflammatory potential of the exhaust by simultaneously increasing its genotoxicity compared to unfiltered reference exhaust produced in absence of any catalyst [34, 37], but that when the same DPF is used (with the same test vehicle at the identical operation point) in combination with a fuel borne catalyst (Satacen ${ }^{\circledR} 3$ ), exhaust genotoxicity can be completely abolished, however, with a certain penalty towards proinflammatory effects. These findings were in-line with what

Table 1 Summary of the effects induced by nonfiltered as well as filtered gasoline exhaust emissions in lung cells in vitro

\begin{tabular}{lll}
\hline & $\begin{array}{l}\text { Without GPF } \\
\text { (i.e., particulate fraction } \\
\text { and volatile compounds) }\end{array}$ & $\begin{array}{l}\text { With GPF } \\
\text { (i.e., volatile } \\
\text { compounds) }\end{array}$ \\
\hline Cytotoxicity & No effect & No effect \\
Cell morphology & No effect & No effect \\
Oxidative stress & Increase & No effect \\
Antioxidative stress & No effect & Increase \\
Pro-inflammation & No effect & Increase \\
AhR activation & Increase & No effect \\
Genotoxicity (Ames test) & Increase & No effect \\
\hline
\end{tabular}

The term oxidative stress is related to the gene expression analysis while antioxidative stress is related to level of the antioxidative protein GSH. The table indicates differences in response compared to filtered air exposures

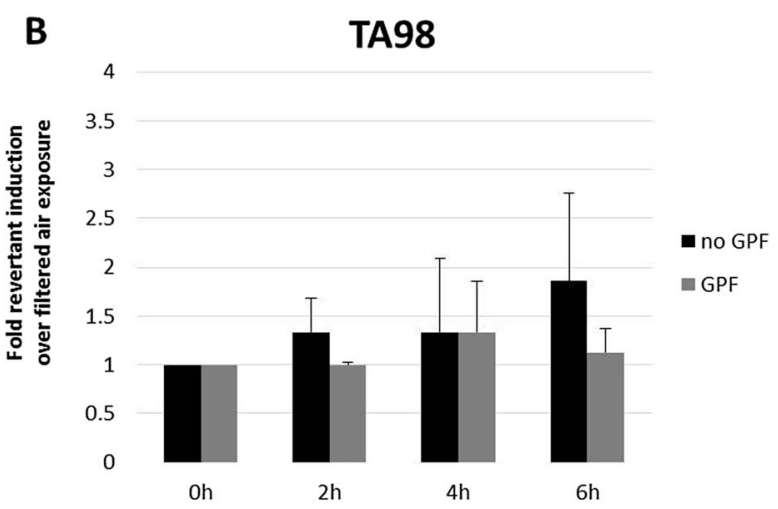

response indicates genotoxic effects. Error bars indicate SEMs. Experimental repetitions are for no GPF $(n=2)$ and for GPF $(n=3)$, except for the treatment with GPF for TA100 at $6 \mathrm{~h}(n=2)$

had been reported in detailed analytical studies investigating how DPFs and the catalytic activity that goes along with them influence the formation or elimination of exhaust components of high genotoxic (and/or pro-inflammatory, oxidative, etc.) potential [51, 52]. The combined conclusions of these studies were as follows:

1. That DPFs may act as chemical reactors in which exhaust components are stored for prolonged periods of time during which they may be chemically modified by the continuous stream of hot, reactive exhaust gases. Importantly, either merely as a function of time or as a function of changed vapor pressure brought by the chemical modifications, the DPF will emit certain components as secondary emissions.

2 . That the secondary emissions are not only detectable analytically but may in fact have profound effects on exhaust toxicity.

3. That therefore a high filtration efficiency of DPF alone is not sufficient for exhaust detoxification but that the catalytic activity the filter provides is at least as important.

It is likely that the findings made for a DPF also apply for a GPF, i.e., that the beneficial effects of the filter may be greatly increased by backing up its high filtration efficiency - which per se can be assumed to have a beneficial effect - with finetuned catalytic activity that does not only efficiently eliminate primary toxic exhaust components but also does not result in the formation of secondary emissions. It is also important to note that our experimental approach represents an acute exposure scenario and cannot account for chronic effects of the various exhaust exposures.

\section{Conclusion}

In summary, our results allow differentiating the contributions of the particulate and the gaseous fraction to the overall 
exhaust effects from a gasoline engine. The GPF used in this study efficiently filters the particle count in both the cold and warm phase of the NEDC. The biological tests showed that the removal of the particulate fraction decreased significantly the AhR activation in human lung cells in vitro; also, the Ames test suggested a lower genotoxicity for filtered gasoline exhaust. However, the GPF exhaust increased GSH oxidation as well as pro-inflammatory effects, i.e., $I L-8$ expression, in the lung cell cultures.

The different toxic profiles in the cell cultures upon exposure to unfiltered and filtered exhaust could be due to the fact that volatile compounds can attach on the particulate fraction and when the particles are filtered those compounds might react differently with the lung cells.

In conclusion, GPF exhaust did not completely reduce the adverse effects of gasoline exhaust in the in vitro test and further experiments with a coated GPF are needed in the future.

Acknowledgments This work was supported by the Adolphe Merkle Foundation, the Swiss Federal Office for Environment, the Swiss Federal Office of Energy, Schweizer Erdölvereinigung, and VERT Association. Furthermore, we would like to thank Dr. Gruenert (University of California, San Francisco) for providing the16HBE14o- cell line.

Conflict of Interest Andreas Mayer is the owner and general manager of "TTM Andreas Mayer," Switzerland, an emission consulting company. As all of the other authors, however, he declares to have no conflicts of interest.

Open Access This article is distributed under the terms of the Creative Commons Attribution 4.0 International License (http:// creativecommons.org/licenses/by/4.0/), which permits unrestricted use, distribution, and reproduction in any medium, provided you give appropriate credit to the original author(s) and the source, provide a link to the Creative Commons license, and indicate if changes were made.

\section{References}

1. Bach, C.: Emissionsvergleich verschiedener Antriebsarten in aktuellen Personenwagen. -Untersuchung der Emissionen von aktuellen Personenwagen mit konventionellen und direkteingespritzten Benzinmotoren, Dieselmotoren mit und ohne Partikelfilter, sowie Erdgasmotoren. (Empa Final Report for Novatlantis and Bundesamt für Umwelt BAFU). EMPA report 2007 (2007)

2. Bielaczyc, P., Szczotka, A., Woodburn, J.: An overview of particulate matter emissions from modern light duty vehicles. Combustion. Engines. 52, (2013)

3. Mayer, A., Czerwinski, J., Kasper, M., Ulrich, A., Mooney, J.J.: Metal Oxide Particle Emissions from Diesel and Petrol Engines. In: SAE Technical Paper, (2012-01-0841)

4. Chan, T.W., Meloche, E., Kubsh, J., Brezny, R., Rosenblatt, D., Rideout, G.: Impact of Ambient Temperature on Gaseous and Particle Emissions from a Direct Injection Gasoline Vehicle and its Implications on Particle Filtration. In: SAE Technical Paper, (2013-01-0527)

5. Buchholz, B.A., Dibble, R.W., Rich, D., Cheng, A.: Quantifying the contribution of lubrication oil carbon to particulate emissions from a diesel engine. In: SAE Technical Paper, (2003-01-1987)

6. Sonntag, D.B., Bailey, C.R., Fulper, C.R., Baldauf, R.W.: Contribution of lubricating oil to particulate matter emissions from light-duty gasoline vehicles in Kansas City. Environ. Sci. Technol. 46(7), 4191-4199 (2012). doi:10.1021/es203747f

7. Lee, K.O., Seong, H., Sakai, S., Hageman, M., Rothamer, D.: Detailed morphological properties of nanoparticles from gasoline direct injection engine combustion of ethanol blends. In: SAE Technical Paper, (2013-24-0185)

8. Mathis, U., Kaegi, R., Mohr, M., Zenobi, R.: TEM analysis of volatile nanoparticles from particle trap equipped diesel and direct-injection spark-ignition vehicles. Atmos. Environ. 38(26), 4347-4355 (2004)

9. Mamakos, A., Martini, G., Dilara, P., Drossinos, Y.: Feasibility of introducing particulate filters on gasoline direct injection vehicles. JRC Scientific and Policy Report, EU Commission (2011)

10. Bruske-Hohlfeld, I.: Environmental and occupational risk factors for lung cancer. Methods Mol. Biol. 472, 3-23 (2009). doi:10. 1007/978-1-60327-492-0 1

11. Wichmann, H.-E.: Diesel exhaust particles. Inhal. Toxicol. 19(S1), 241-244 (2007)

12. Ema, M., Naya, M., Horimoto, M., Kato, H.: Developmental toxicity of diesel exhaust: a review of studies in experimental animals. Reprod. Toxicol. 42, 1-17 (2013). doi:10.1016/j.reprotox.2013.06. 074

13. Rothen-Rutishauser, B., Blank, F., Muhlfeld, C., Gehr, P.: In vitro models of the human epithelial airway barrier to study the toxic potential of particulate matter. Expert Opin. Drug Metab. Toxicol. 4(8), 1075-1089 (2008). doi:10.1517/17425255.4.8.1075

14. Rothen-Rutishauser, B.M., Kiama, S.G., Gehr, P.: A three-dimensional cellular model of the human respiratory tract to study the interaction with particles. Am. J. Respir. Cell Mol. Biol. 32(4), 281-289 (2005). doi:10.1165/rcmb.2004-01870C

15. Blank, F., Rothen-Rutishauser, B.M., Schurch, S., Gehr, P.: An optimized in vitro model of the respiratory tract wall to study particle cell interactions. J. Aerosol Med.: Off. J. Int. Soc. Aerosol. Med. 19(3), 392-405 (2006). doi:10.1089/jam.2006.19.392

16. Muller, L., Riediker, M., Wick, P., Mohr, M., Gehr, P., RothenRutishauser, B.: Oxidative stress and inflammation response after nanoparticle exposure: differences between human lung cell monocultures and an advanced three-dimensional model of the human epithelial airways. J. R. Soc. Interface 7(Suppl 1), S27-S40 (2010). doi:10.1098/rsif.2009.0161.focus

17. Clift, M.J., Endes, C., Vanhecke, D., Wick, P., Gehr, P., Schins, R.P., Petri-Fink, A., Rothen-Rutishauser, B.: A comparative study of different in vitro lung cell culture systems to assess the most beneficial tool for screening the potential adverse effects of carbon nanotubes. J. Toxicol. Sci. : Off. J. Soc. Toxicol. 137(1), 55-64 (2014). doi:10.1093/toxsci/kft216

18. Clift, M.J., Foster, E.J., Vanhecke, D., Studer, D., Wick, P., Gehr, P., Rothen-Rutishauser, B., Weder, C.: Investigating the interaction of cellulose nanofibers derived from cotton with a sophisticated 3D human lung cell coculture. Biomacromolecules 12(10), 3666-3673 (2011). doi:10.1021/bm200865j

19. Brandenberger, C., Rothen-Rutishauser, B., Muhlfeld, C., Schmid, O., Ferron, G.A., Maier, K.L., Gehr, P., Lenz, A.G.: Effects and uptake of gold nanoparticles deposited at the air-liquid interface of a human epithelial airway model. Toxicol. Appl. Pharmacol. 242(1), 56-65 (2010). doi:10.1016/j.taap.2009.09.014

20. Lenz, A.G., Karg, E., Lentner, B., Dittrich, V., Brandenberger, C., Rothen-Rutishauser, B., Schulz, H., Ferron, G.A., Schmid, O.: A dose-controlled system for air-liquid interface cell exposure and 
application to zinc oxide nanoparticles. Part. Fibre Toxicol. 6, 32 (2009). doi:10.1186/1743-8977-6-32

21. Muller, L., Comte, P., Czerwinski, J., Kasper, M., Mayer, A.C., Gehr, P., Burtscher, H., Morin, J.P., Konstandopoulos, A., Rothen-Rutishauser, B.: New exposure system to evaluate the toxicity of (scooter) exhaust emissions in lung cells in vitro. Environ. Sci. Technol. 44(7), 2632-2638 (2010). doi:10.1021/es903146g

22. Clift, M.J., Gehr, P., Rothen-Rutishauser, B.: Nanotoxicology: a perspective and discussion of whether or not in vitro testing is a valid alternative. Arch. Toxicol. 85(7), 723-731 (2011). doi:10. 1007/s00204-010-0560-6

23. Clift, M.J., Raemy, D.O., Endes, C., Ali, Z., Lehmann, A.D., Brandenberger, C., Petri-Fink, A., Wick, P., Parak, W.J., Gehr, P., Schins, R.P., Rothen-Rutishauser, B.: Can the Ames test provide an insight into nano-object mutagenicity? Investigating the interaction between nano-objects and bacteria. Nanotoxicology 7(8), 13731385 (2013). doi:10.3109/17435390.2012.741725

24. Gasser, M., Wick, P., Clift, M.J., Blank, F., Diener, L., Yan, B., Gehr, P., Krug, H.F., Rothen-Rutishauser, B.: Pulmonary surfactant coating of multi-walled carbon nanotubes (MWCNTs) influences their oxidative and pro-inflammatory potential in vitro. Part. Fibre Toxicol. 9, 17 (2012). doi:10.1186/1743-8977-9-17

25. Steiner, S., Mueller, L., Popovicheva, O.B., Raemy, D.O., Czerwinski, J., Comte, P., Mayer, A., Gehr, P., RothenRutishauser, B., Clift, M.J.: Cerium dioxide nanoparticles can interfere with the associated cellular mechanistic response to diesel exhaust exposure. Toxicol. Lett. 214(2), 218-225 (2012). doi:10. 1016/j.toxlet.2012.08.026

26. Cooney, D.J., Hickey, A.J.: Cellular response to the deposition of diesel exhaust particle aerosols onto human lung cells grown at the air-liquid interface by inertial impaction. Toxicol. in Vitro 25(8), 1953-1965 (2011). doi:10.1016/j.tiv.2011.06.019

27. Kooter, I.M., Alblas, M.J., Jedynska, A.D., Steenhof, M., Houtzager, M.M., van Ras, M.: Alveolar epithelial cells (A549) exposed at the air-liquid interface to diesel exhaust: First study in TNO's powertrain test center. Toxicol. in Vitro 27(8), 2342-2349 (2013). doi:10.1016/j.tiv.2013.10.007

28. Morin, J.P., Hasson, V., Fall, M., Papaioanou, E., Preterre, D., Gouriou, F., Keravec, V., Konstandopoulos, A., Dionnet, F.: Prevalidation of in vitro continuous flow exposure systems as alternatives to in vivo inhalation safety evaluation experimentations: outcome from MAAPHRI-PCRD5 research program. Exp. Toxicol. Pathol. 60(2-3), 195-205 (2008). doi:10.1016/j.etp.2008. 01.007

29. Müller, L., Comte, P., Czerwinski, J., Kasper, M., Mayer, A.C.R., Schmid, A., Rosinus, L., Clift, M.J.D., Steiner, S., Gehr, P., RothenRutishauser, B.: Investigating the potential for different scooter and car exhaust emissions to cause cytotoxic and (pro-)inflammatory responses to a $3 \mathrm{D}$ in vitro model of the human epithelial airway. Toxicol. Environ. Chem. 94(1), 164-180 (2011). doi:10.1080/ 02772248.2011.632509

30. Brito, J.M., Belotti, L., Toledo, A.C., Antonangelo, L., Silva, F.S., Alvim, D.S., Andre, P.A., Saldiva, P.H., Rivero, D.H.: Acute cardiovascular and inflammatory toxicity induced by inhalation of diesel and biodiesel exhaust particles. J. Toxicol. Sci. : Off. J. Soc. Toxicol. 116(1), 67-78 (2010). doi:10.1093/toxsci/kfq107

31. Finch, G.L., Hobbs, C.H., Blair, L.F., Barr, E.B., Hahn, F.F., Jaramillo, R.J., Kubatko, J.E., March, T.H., White, R.K., Krone, J.R., Menache, M.G., Nikula, K.J., Mauderly, J.L., Van Gerpen, J., Merceica, M.D., Zielinska, B., Stankowski, L., Burling, K., Howell, S.: Effects of subchronic inhalation exposure of rats to emissions from a diesel engine burning soybean oil-derived biodiesel fuel. Inhal. Toxicol. 14(10), 1017-1048 (2002). doi:10.1080/ 08958370290084764

32. Müller, L., Gasser, M., Raemy, D.O., Herzog, F., Brandenberger, C., Schmid, O., Gehr, P., Rothen-Rutishauser, B., Clift, M.J.:
Realistic exposure methods for investigating the interaction of nanoparticles with the lung at the air-liquid interface in vitro. Insciences J. 1(1), 30-64 (2011)

33. Paur, H.-R., Cassee, F.R., Teeguarden, J., Fissan, H., Diabate, S., Aufderheide, M., Kreyling, W.G., Hänninen, O., Kasper, G., Riediker, M.: In-vitro cell exposure studies for the assessment of nanoparticle toxicity in the lung - a dialog between aerosol science and biology. J. Aerosol Sci. 42(10), 668-692 (2011)

34. Steiner, S., Czerwinski, J., Comte, P., Muller, L.L., Heeb, N.V., Mayer, A., Petri-Fink, A., Rothen-Rutishauser, B.: Reduction in (pro-)inflammatory responses of lung cells exposed in vitro to diesel exhaust treated with a non-catalyzed diesel particle filter. Atmos. Environ. 81, 117-124 (2013). doi:10.1016/j.atmosenv.2013.08.029

35. Cozens, A.L., Yezzi, M.J., Kunzelmann, K., Ohrui, T., Chin, L., Eng, K., Finkbeiner, W.E., Widdicombe, J.H., Gruenert, D.C.: CFTR expression and chloride secretion in polarized immortal human bronchial epithelial cells. Am. J. Respir. Cell Mol. Biol. 10(1), 38-47 (1994). doi:10.1165/ajrcmb.10.1.7507342

36. Steiner, S., Czerwinski, J., Comte, P., Popovicheva, O., Kireeva, E., Muller, L., Heeb, N., Mayer, A., Fink, A., Rothern-Rutishauser, B.: Comparison of the toxicity of diesel exhaust produced by bio- and fossil diesel combustion in human lung cells in vitro. Atmos. Environ. 81, 380-388 (2013). doi:10.1016/j.atmosenv.2013.08.059

37. Steiner, S., Czerwinski, J., Comte, P., Heeb, N.V., Mayer, A., PetriFink, A., Rothen-Rutishauser, B.: Effects of an iron-based fuelborne catalyst and a diesel particle filter on exhaust toxicity in lung cells in vitro. Anal. Bioanal. Chem. (2014). doi:10.1007/s00216014-7878-5

38. Steiner, S., Heeb, N.V., Czerwinski, J., Comte, P., Mayer, A., PetriFink, A., Rothen-Rutishauser, B.: Test-methods on the test-bench: a comparison of complete exhaust and exhaust particle extracts for Genotoxicity/Mutagenicity assessment. Environ. Sci. Technol. 48(9), 5237-5244 (2014). doi:10.1021/Es4056033

39. Cumming, G., Finch, S.: Inference by eye - Confidence intervals and how to read pictures of data. Am. Psychol. 60(2), 170-180 (2005). doi:10.1037/0003-066x.60.2.170

40. Steiner, S., Czerwinski, J., Comte, P., Mayer, A., Heeb, N., Fink, A., Rothen-Rutishauser, B.: A New Standard approach for rapid and reliable screening of exhaust emission toxicity in $3 \mathrm{~d}$ lung models in vitro. J. Aerosol Med. Pulm. Drug Deliv. 26(2), A61-A61 (2013)

41. Weingartner, E., Keller, C., Stahel, W., Burtscher, H., Baltensperger, U.: Aerosol emission in a road tunnel. Atmos. Environ. 31(3), 451-462 (1997)

42. Westerdahl, D., Fruin, S., Sax, T., Fine, P.M., Sioutas, C.: Mobile platform measurements of ultrafine particles and associated pollutant concentrations on freeways and residential streets in Los Angeles. Atmos. Environ. 39(20), 3597-3610 (2005). doi:10. 1016/j.atmosenv.2005.02.034

43. Tartakovsky, L., Baibikov, V., Czerwinski, J., Gutman, M., Kasper, M., Popescu, D., Veinblat, M., Zvirin, Y.: In-vehicle particle air pollution and its mitigation. Atmos. Environ. 64, 320-328 (2013). doi:10.1016/j.atmosenv.2012.10.003

44. Reed, M.D., Barrett, E.G., Campen, M.J., Divine, K.K., Gigliotti, A.P., McDonald, J.D., Seagrave, J.C., Mauderly, J.L., Seilkop, S.K., Swenberg, J.A.: Health effects of subchronic inhalation exposure to gasoline engine exhaust. Inhal. Toxicol. 20(13), 1125-1143 (2008). doi:10.1080/08958370802368722

45. Lund, A.K., Knuckles, T.L., Obot Akata, C., Shohet, R., McDonald, J.D., Gigliotti, A., Seagrave, J.C., Campen, M.J.: Gasoline exhaust emissions induce vascular remodeling pathways involved in atherosclerosis. J. Toxicol. Sci. : Off. J. Soc. Toxicol. 95(2), 485-494 (2007). doi:10.1093/toxsci/kfl145

46. Guo, J., Kauppinen, T., Kyyronen, P., Lindbohm, M.L., Heikkila, P., Pukkala, E.: Occupational exposure to diesel and gasoline engine exhausts and risk of lung cancer among Finnish workers. Am. J. Ind. Med. 45(6), 483-490 (2004). doi:10.1002/ajim.20013 
47. Parent, M.E., Rousseau, M.C., Boffetta, P., Cohen, A., Siemiatycki, $\mathrm{J}$.: Exposure to diesel and gasoline engine emissions and the risk of lung cancer. Am. J. Epidemiol. 165(1), 53-62 (2007). doi:10.1093/ aje/kwj343

48. Villeneuve, P.J., Parent, M.E., Sahni, V., Johnson, K.C.: Canadian cancer registries epidemiology research, G.: occupational exposure to diesel and gasoline emissions and lung cancer in Canadian men. Environ. Res. 111(5), 727-735 (2011). doi:10.1016/j.envres.2011.04.003

49. Vrzal, R., Ulrichova, J., Dvorak, Z.: Aromatic hydrocarbon receptor status in the metabolism of xenobiotics under normal and pathophysiological conditions. Biomed. Pap. Med. Fac. Univ. Palacky Olomouc Czech Repub. 148(1), 3-10 (2004)

50. Hankinson, O.: The aryl hydrocarbon receptor complex. Annu. Rev. Pharmacol. Toxicol. 35, 307-340 (1995). doi:10.1146/ annurev.pa.35.040195.001515
51. Heeb, N.V., Schmid, P., Kohler, M., Gujer, E., Zennegg, M., Wenger, D., Wichser, A., Ulrich, A., Gfeller, U., Honegger, P., Zeyer, K., Emmenegger, L., Petermann, J.L., Czerwinski, J., Mosimann, T., Kasper, M., Mayer, A.: Impact of low- and highoxidation diesel particulate filters on genotoxic exhaust constituents. Environ. Sci. Technol. 44(3), 1078-1084 (2010). doi:10. 1021/es9019222

52. Heeb, N.V., Schmid, P., Kohler, M., Gujer, E., Zennegg, M., Wenger, D., Wichser, A., Ulrich, A., Gfeller, U., Honegger, P., Zeyer, K., Emmenegger, L., Petermann, J.L., Czerwinski, J., Mosimann, T., Kasper, M., Mayer, A.: Secondary effects of catalytic diesel particulate filters: conversion of PAHs versus formation of nitro-PAHs. Environ. Sci. Technol. 42(10), 3773-3779 (2008) 